\title{
Survivin expression in canine spontaneous cutaneous and subcutaneous tumors and its prognostic importance
}

\author{
N. Kavya ${ }^{1}$, S. Rao ${ }^{1}$, M. L. Sathyanarayana ${ }^{1}$, H. D. Narayanaswamy ${ }^{1}$, S. M. Byregowdaㄹ ${ }^{2}$ L. Ranganath ${ }^{3}$, A. Kamaran ${ }^{4}$,
} K. M. Purushotham² and T. K. Kishore ${ }^{1}$

\begin{abstract}
1. Department of Veterinary Pathology, Veterinary College, Karnataka Veterinary Animal and Fisheries Sciences University, Bengaluru, Karnataka, India; 2. Department of Biotechnology, Institute of Animal Health and Veterinary Biologicals, Veterinary College, Karnataka Veterinary Animal and Fisheries Sciences University, Bengaluru, Karnataka, India; 3. Department of Veterinary Surgery and Radiology, Veterinary College, Karnataka Veterinary Animal and Fisheries Sciences University, Bengaluru, Karnataka, India; 4. Department of Veterinary Medicine, Veterinary College, Karnataka Veterinary Animal and Fisheries Sciences University, Bengaluru, Karnataka, India.

Corresponding author: N. Kavya, e-mail: kavyavetico@gmail.com

Co-authors: SR: sugunabg@gmail.com, MLS: mlspathology@yahoo.com,HDN: drhdnswamy9@gmail.com, SMB: smbyregowda@gmail.com, LR: lingapparanganath@gmail.com, AK: drcansarkamran@gmail.com, KMP: drkmpu@gmail.com, TKK: Kishvety599@gmail.com

Received: 07-06-2017, Accepted: 21-09-2017, Published online: 31-10-2017
\end{abstract}

doi: 10.14202/vetworld.2017.1286-1291 How to cite this article: Kavya N, Rao S, Sathyanarayana ML, Narayanaswamy HD, Byregowda SM, Ranganath L, Kamaran A, Purushotham KM, Kishore TK (2017) Survivin expression in canine spontaneous cutaneous and subcutaneous tumors and its prognostic importance, Veterinary World, 10(10): 1286-1291.

\begin{abstract}
Aim: The present study was carried out to know the expression level of survivin, an inhibitor of apoptosis protein with an objective to determine its prognostic importance in cutaneous and subcutaneous tissue tumors of dogs.

Materials and Methods: Forty cases of canine cutaneous and subcutaneous tissue tumors on histopathological examination revealed various round cell, epithelial, and mesenchymal cell tumors. Survivin gene expression was detected in all tumors tested by TaqMan real-time polymerase chain reaction assay by comparative cycle threshold method.

Results: The mean survivin gene expression value of benign tumors was $0.94 \pm 0.63$ folds and that of malignant tumors was $18.87 \pm 5.30$ folds. Postsurgical follow up of 30 malignant tumor cases revealed death in 8 , recurrence in 7 , and neoplastic free alive status in 15 dogs with mean survivin fold difference values of $48.49 \pm 12.39,14.63 \pm 6.37$, and $5.034 \pm 2.27$, respectively. The mean survivin gene expression value was significantly higher in malignant (30 cases, 18.87 \pm 5.30$)$ compared to benign tumors (10 cases, $0.94 \pm 0.63)$, and it varied between various postsurgical follow-up groups $(p<0.05)$. Survival analysis, using survivin gene expression median cutoff value of 3.74 in 30 malignant tumors, was performed to predict probable survival period in malignant cutaneous and subcutaneous tumors of dogs.
\end{abstract}

Conclusion: Results of the present study indicated that the expression of survivin in canine cutaneous and subcutaneous tumors has prognostic value, and survivin expression greater than median cutoff value of 3.74 has a poor prognosis.

Keywords: cutaneous and subcutaneous tumors, prognostic value, quantitative real-time polymerase chain reaction, survivin.

\section{Introduction}

Cancer is a consequence of imbalance between cell death and proliferation in a way favorable to cell proliferation and survival [1]. In the recent years, cancer has been reported to be a leading cause of mortality in dogs and second most in humans [2]. Cutaneous and subcutaneous tissue tumors account for approximately one-third of all the tumors encountered in dogs $[3,4]$ with most common types being epithelial tumors, followed by round cell tumors and mesenchymal tumors [5-7]. The peak age of affection in dogs is 8-10 years [8], and breed and sex of dogs have no significant influence on the incidence of skin

Copyright: Kavya, et al. Open Access. This article is distributed under the terms of the Creative Commons Attribution 4.0 International License (http://creativecommons.org/licenses/by/4.0/), which permits unrestricted use, distribution, and reproduction in any medium, provided you give appropriate credit to the original author(s) and the source, provide a link to the Creative Commons license, and indicate if changes were made. The Creative Commons Public Domain Dedication waiver (http://creativecommons.org/ publicdomain/zero/1.0/) applies to the data made available in this article, unless otherwise stated. tumors $[7,9,10]$. Approximately $20-40 \%$ of primary tumors of the skin and subcutaneous tissues are histologically malignant in the dogs [7] and have a higher tendency of recurrence and metastasis to visceral organs, resulting in reduced survival time and rate of affected dogs $[11,12]$. Hence, accurate diagnosis of malignancy at the earliest stage is one of the requirements for effective management of cancers. Recent advances in tumor biology have identified a number of markers that may form a basis for tumor diagnosis and prognosis [13].

Inhibitors of apoptosis proteins (IAPs) are a family of tumor markers that interfere with the activation of caspases [14]. Survivin, one of the members of IAP is a bifunctional protein that regulates cell division and suppresses apoptosis [15]. Although survivin is abundantly expressed in fetal tissues, it is undetectable in most normal, terminally differentiated adult tissues [16]. It is overexpressed in a variety of human neoplasms including breast $[17,18]$, esophagus [19], stomach [20,21], colon [22], pancreas [23], 
bladder [24], renal cell [25], head and neck [26], oral [27], and leukemias [28], suggesting that reactivation of the survivin gene frequently occurs in cancers [29].

High survivin expression by neoplasms correlates with more aggressive behavior, decreased response to chemotherapeutic agents, and shortened survival time as compared to cancers that are survivin negative [29]. Intensive survivin research is currently ongoing in human field, which is being used as a prognostic factor in several human neoplasms. Its expression in companion animals has limited investigation, and hence, the present study was carried out to know the expression level of survivin with an objective to determine its prognostic importance in cutaneous and subcutaneous tissue tumors of dogs.

\section{Materials and Methods \\ Ethical approval}

Ethical approval is not necessary for such type of clinical cases. However, surgery was conducted upon consent from owner and as per standard surgical methods.

\section{Place of study}

This study was conducted in the Department of Veterinary Pathology, Veterinary College, Hebbal, Bengaluru, during 2015-2016, on 40 cases of cutaneous and subcutaneous tissue tumors of dogs presented to the Department of Veterinary Surgery, Veterinary College, Bengaluru.

\section{Study animals and sample collection}

Breed of dogs encountered in the present study was mongrels (13), followed by Labrador Retriever (8), Boxer (5), German Shepherd (4), Pomeranian (3), Golden Retriever (2), and Doberman (2). The other breeds which were affected lesser were Pug, Dalmatian, and Rottweiler. Apart from visible skin masses, patients were declared as healthy based on pre-operative hematological and serological parameters. On owner's consent, surgery was carried out for cutaneous masses, and tissues were collected for histopathological processing. A follow-up study for a minimum period of 8 months was carried out postsurgically in all the dogs.

\section{Histopathology}

Representative tissue samples obtained after surgical excision were fixed in $10 \%$ neutral buffered formalin and processed by routine paraffin-embedding technique. Sections of 4-5 $\mu \mathrm{m}$ thickness were taken, and cut sections were stained with hematoxyline and eosin. Tissue sections were examined to record and classify the cutaneous and subcutaneous tumors.

Quantitative real-time (q-RT)-polymerase chain reaction (PCR) for survivin mRNA expression

Total RNA was isolated using TRIzol ${ }^{\circledR}$ ready to use solution procured from $\mathrm{M} / \mathrm{s}$ Invitrogen (USA) and used as per manufacturer's recommendations. Complementary DNA (catalog no. 3B 120, biotools B and M Labs, Spain) was prepared for RNA sequences encoding survivin gene of dog using gene-specific primers. Quantitative TaqMan RT-PCR (catalog no. 3B 108, biotools B and M Labs, Spain) assay was carried out for survivin (antiapoptotic protein) and glyceraldehyde-3-phosphate dehydrogenase (GAPDH) (housekeeping gene) mRNA using the Thermal cycler (EPPENDORF realplex 2.2) instrument according to the manufacturer's instructions. Published sequences available in the gene bank were used for the designing of required primers for the study. Primers were designed using primer blast (http://www.ncbi.nlm.nih.gov/tools/ primerblast/), Genscript ${ }^{\circledR}$ (https://www.genscript.com/ sslbin/app/primer), and primer3plus ${ }^{\mathbb{B}}$ (http://www. bioinformatics.nl/cgibin/primer3 plus/primer3plus. cgi/) sequence analyzing software's and procured from Bioserve Biotechnologies (India) Pvt Ltd.

The published reference sequence of survivin for dog was from NCBI No: NM-001003348 (Table-1).

RT-PCR amplification reaction was carried out in a $20 \mu 1$ reaction mixture containing $10 \mu \mathrm{l}$ each of mastermix (3B quantimix), and samples were used in duplicate. Relative gene quantification was done by comparative $\mathrm{Ct}$ method, and the values were expressed as relative to the reference sample used, as calibrator (Tables-2 and 3).

\section{Statistical analysis}

Statistical analysis was performed using the statistical software $\mathrm{R}$ version 3.2.4 Revised Copyright (C) 2016 (R-bloggers.com). Mean values and standard error of the mean were calculated, and all values were expressed as mean \pm standard error. The data were analyzed by t-test unpaired, ANOVA-Tukey test was used for finding the source of the differences in multiple groups, and Kaplan-Meier survival curve analysis and curve were compared by log-rank test. For all statistical analysis, $\mathrm{p}<0.05$ was considered statistically significant.

Table-1: Primers and probes used for q-RT-PCR.

\begin{tabular}{lllr}
\hline Primer code & & Primer sequence & Product size (bp) \\
\hline Canine survivin F & $5^{\prime}-3^{\prime}$ & TCATCTGGTTGTGCTTCCT & 88 \\
Canine survivin R & $5^{\prime}-3^{\prime}$ & TGGCTCTTCTTGTCCAGT & 106 \\
Survivin probe & $3^{\prime}-5^{\prime}$ & TCTGTCAAGAAGCAGTTTGAAGA & \\
GAPDH F & $5^{\prime}-3^{\prime}$ & ATGACTCTACCCACGGCAAG & \\
GAPDH R & $5^{\prime}-3^{\prime}$ & TACTCAGCACCAGCATCACC & \\
GAPDH probe & $5^{\prime}-3^{\prime}$ & AAACCCATCACCATCTTCCAG & \\
\hline
\end{tabular}

q-RT-PCR=Quantitative real-time-polymerase chain reaction, GAPDH=Glyceraldehyde-3-phosphate dehydrogenase

Veterinary World, EISSN: 2231-0916 
Table-2: Thermal cycling conditions for amplification of dog GAPDH gene.

\begin{tabular}{lccc}
\hline Stage & Temperature $\left({ }^{\circ} \mathbf{C}\right)$ & Duration & $\begin{array}{c}\text { Number } \\
\text { of cycles }\end{array}$ \\
\hline $\begin{array}{l}\text { Initial } \\
\text { denaturation } \\
\begin{array}{l}\text { Denaturation } \\
\text { of cDNA }\end{array}\end{array}$ & 95 & $3 \mathrm{~min}$ & 1 \\
$\begin{array}{l}\text { Annealing of } \\
\text { primers }\end{array}$ & 95 & $5 \mathrm{~s}$ & 40 \\
Extension & 59.6 & $20 \mathrm{~s}$ & \\
\hline
\end{tabular}

GAPDH=Glyceraldehyde-3-phosphate dehydrogenase

Table-3: Thermal cycling conditions for amplification of dog survivin gene.

\begin{tabular}{lccc}
\hline Stage & Temperature $\left({ }^{\circ} \mathbf{C}\right)$ & Duration & $\begin{array}{c}\text { Number } \\
\text { of cycles }\end{array}$ \\
\hline $\begin{array}{l}\text { Initial } \\
\text { denaturation }\end{array}$ & $95 \mathrm{~s}$ & $3 \mathrm{~min}$ & 1 \\
$\begin{array}{l}\text { Denaturation } \\
\text { of cDNA }\end{array}$ & 95 & $5 \mathrm{~s}$ & 40 \\
$\begin{array}{l}\text { Annealing of } \\
\text { primers }\end{array}$ & 52 & $20 \mathrm{~s}$ & \\
\begin{tabular}{l} 
Extension \\
\hline
\end{tabular} & 65 & $20 \mathrm{~s}$ & \\
\hline
\end{tabular}

\section{Results}

In this study, 40 cutaneous and subcutaneous tumors were classified based on the predominant cell type and histological characteristics (Figure-1) as round cell tumors ( 8 cases, $20 \%$ ), epithelial tumors ( 23 cases, $57.5 \%$ ), and mesenchymal tumors ( 9 cases, $22.5 \%)$. Out of 40 cases, $30(75 \%)$ were malignant and remaining $10(25 \%)$ were benign tumors. The malignant tumors predominated over the benign types in the present study, and epithelial tumors predominated over other types.

All the 40 tumor cases were subjected for immunohistochemistry to know the expression profile of survivin using EP 119 rabbit monoclonal primary antibody raised against human survivin protein which was procured from PathnSitu, Bengaluru. In positive control sections of human breast cancer tissues, the EP 119 monoclonal antibody reacted well and detected the survivin antigen (PathnSitu, Bengaluru). However, the application of IHC technique using anti-survivin EP119 antibody on normal and tumorous canine cutaneous and subcutaneous tissue did not yield any reaction on repeated testing with modifications in antigen retrieval methods and immunostaining incubation period as well as incubation temperature. Hence, the survivin gene expression to determine its prognostic value in the present study was carried out by RT-PCR on tumor tissues for its relative quantification.

Relative quantification of survivin gene was carried out to determine the level of expression of survivin gene in malignant and benign cutaneous and subcutaneous tumor tissues and normal canine skin tissues as control. The survivin gene expression in malignant tumors varied from 1.21 to 95.01

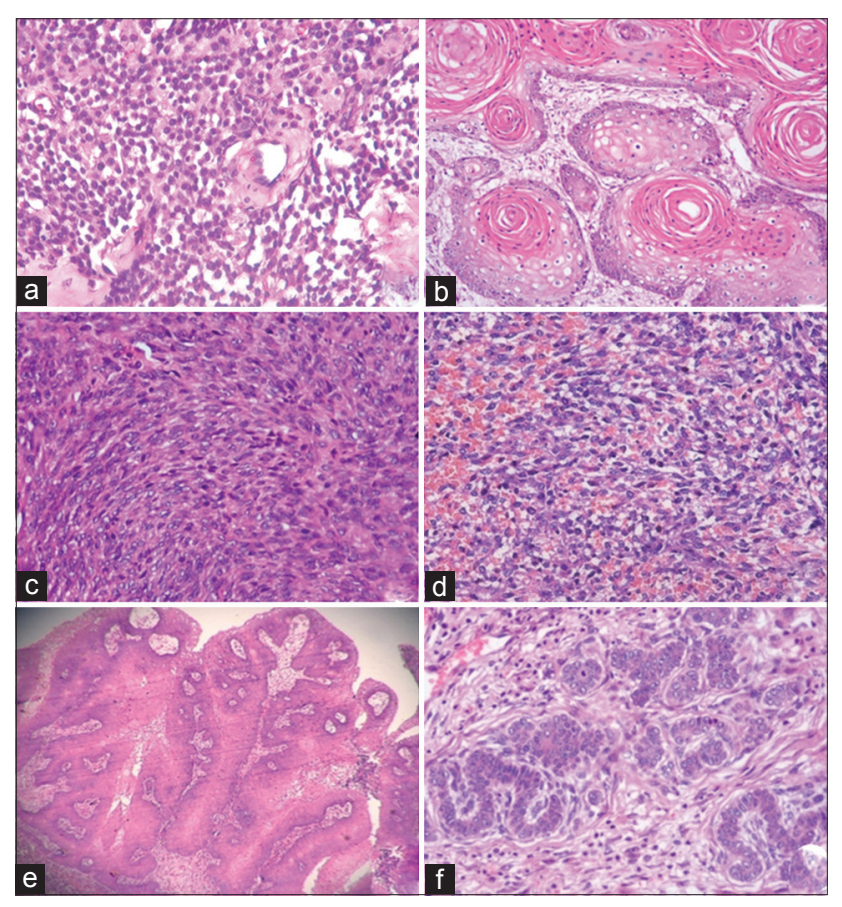

Figure-1: Histopathological images of various cutaneous and subcutaneous tumors $\mathrm{H}$ and $\mathrm{E}$. (a) Mast cell tumor, (b) squamous cell carcinoma, (c) fibrosarcoma, (d) hemangiosarcoma, (e) squamous papilloma, and (f) trichoblastoma.

folds, and among benign tumors, it was 0.01-8.4 folds. The mean survivin gene expression of benign tumors was $0.94 \pm 0.63$ folds and that of malignant tumors was $18.87 \pm 5.30$ folds. Among all the malignant tumors, highest mean survivin gene expression value was observed in sweat gland adenocarcinoma (65.26 \pm 29.75$)$, and the least expression was in malignant trichoepithelioma (1.96 \pm 0.75$)$ (Table-4). Statistical analysis revealed that the mean expression of survivin gene was significantly higher $(p<0.05)$ in malignant tumors.

To determine the prognostic value of survivin gene expression, a follow-up study was conducted for 30 malignant cutaneous and subcutaneous tumors for a minimum period of 8 months. There were deaths in 8 cases, recurrence in 7 cases, and disease-free status in 15 cases postsurgically. The median cutoff value of survivin gene expression for 30 malignant cutaneous and subcutaneous tumors tissues was 3.74. The tumors bearing expression value more than median cutoff were considered as overexpressed and those with less than median value as underexpressed. Among 30 malignant tumors, $15(50 \%)$ cases showed overexpression, and $15(50 \%)$ showed underexpression (Table-5). There was overexpression of survivin gene in all the 8 cases that died and the tumors encountered were mammary tumors, sweat gland tumor, and mesenchymal tumors such as fibrosarcoma and hemangiosarcoma. Among the 7 cases that showed recurrence, survivin was overexpressed in 4 cases with squamous cell carcinoma being the most common tumor, and rest of the 3 cases showed underexpression. In the alive group of tumor 
Table-4: Mean \pm SE of survivin gene expression values of different cutaneous and subcutaneous tumors $(n=40)$.

\begin{tabular}{|c|c|c|}
\hline Type of tumor & Number of cases & Mean \pm SE survivin gene expression \\
\hline \multicolumn{3}{|l|}{ Round cell tumors $(n=8)$} \\
\hline \multicolumn{3}{|l|}{ Malignant type } \\
\hline Mast cell tumor & 4 & $25.57 \pm 20.74$ \\
\hline Histiocytoma & 3 & $2.23 \pm 0.48$ \\
\hline Transmissible venereal tumor & 1 & 5.28 \\
\hline \multicolumn{3}{|l|}{ Epithelial tumors $(n=23)$} \\
\hline \multicolumn{3}{|l|}{ Benign type $(n=7)$} \\
\hline Fibropapilloma & 1 & 0.01 \\
\hline Squamous papilloma & 1 & 0.03 \\
\hline Benign trichoblastoma & 2 & $5.1 \pm 3.3$ \\
\hline Acanthomatous ameloblastoma (Epulis) & 1 & 0.3 \\
\hline Pilomatricoma & 2 & $0.015 \pm 0.01$ \\
\hline \multicolumn{3}{|l|}{ Malignant type $(n=16)$} \\
\hline Squamous cell carcinoma & 5 & $22.02 \pm 15.88$ \\
\hline Malignant trichoepithelioma & 2 & $1.96 \pm 0.75$ \\
\hline Hepatoid gland adenocarcinoma & 3 & $17.04 \pm 15.4$ \\
\hline Sweat gland carcinoma & 2 & $65.26 \pm 29.75$ \\
\hline Solid adenocarcinoma of mammary gland & 2 & $38.33 \pm 24.7$ \\
\hline Complex adenocarcinoma of mammary gland & 1 & 10.93 \\
\hline Simple adenocarcinoma of mammary gland & $1 \mathrm{~s}$ & 23.59 \\
\hline \multicolumn{3}{|l|}{ Mesenchymal tumors $(n=9)$} \\
\hline \multicolumn{3}{|l|}{ Benign type $(n=3)$} \\
\hline Lipoma & 1 & 0.27 \\
\hline Hemangioma & 1 & 1.81 \\
\hline Fibroma & 1 & 0.01 \\
\hline \multicolumn{3}{|l|}{ Malignant type $(n=6)$} \\
\hline Fibrosarcoma & 3 & $4.39 \pm 2.01$ \\
\hline Hemangiosarcoma & 3 & $9.86 \pm 6.4$ \\
\hline
\end{tabular}

SE $=$ Standard error

Table-5: Subdivision of various postsurgical outcome groups using median cutoff value of survivin gene expression (3.74).

\begin{tabular}{lccc}
\hline Survivin expression & Alive (\%) & Dead (\%) & Recurrence (\%) \\
\hline Survivin expression<3.74 (underexpression) & $12(80)$ & $0(0)$ & $3(42.86)$ \\
Survivin expression>3.74 (overexpression) & $3(20)$ & $8(100)$ & $4(57.14)$ \\
\hline
\end{tabular}

cases, 12 showed underexpression of survivin and three showed overexpression.

A statistically significant $(\mathrm{p}<0.05)$ difference in expression of survivin was observed between dead and disease-free alive groups. However, no significant difference was observed between alive and recurrence groups (Table-6). In assessing longterm results of the surgical treatment using KaplanMeier survival curves of follow-up period of dogs revealed statistically significant $(\mathrm{p} \leq 0.05)$ difference in survival time between dogs having survivin gene expression values above and below the median cutoff value of 3.74. At 0.5 level of probability, the mean survival time for dogs with survivin gene expression values more than the median value was found to be 6 months and less than the median value was undefined (Figure-2).

\section{Discussion}

Canine survivin is $91.5 \%$ homologous to its human counterpart at the amino acid level [30]. The expression level of survivin gene depends on several variables such as degree of differentiation of tumor, histologic grade, mitotic index, and type of tumor.

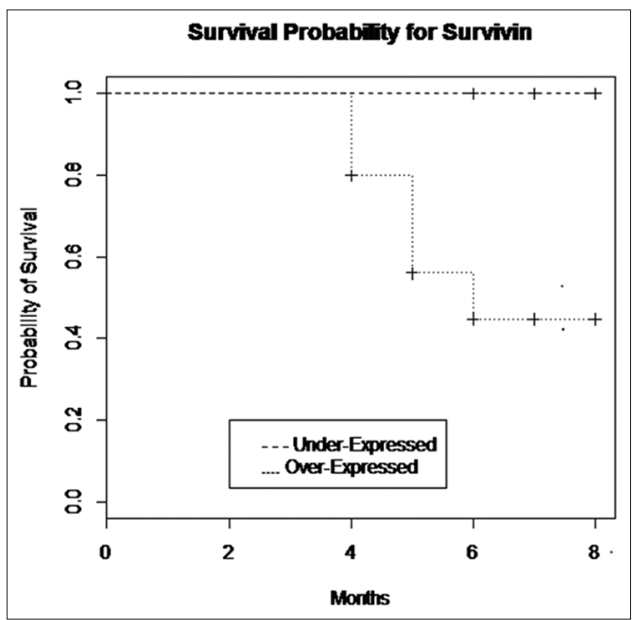

Figure-2: Kaplan-Meier survival curves for dogs with malignant tumors having survivin gene expression more than and less than the calculated median value of 3.74 $(p \leq 0.05)$.

The gene expression is lower in well-differentiated tumors with histologic grade zero, and mature cells do not show survivin expression [31,32]. However, reactivation of the survivin gene frequently occurs in neoplastic processes. 
Table-6: Mean \pm SE of survivin gene expression in various postsurgical outcome groups.

\begin{tabular}{lcc}
\hline Follow-up data & Total number of cases and percentage & Mean \pm SE of survivin gene expression \\
\hline Alive & $15(50)$ & $5.03 \pm 2.27^{\mathrm{a}}$ \\
Recurrence & $7(23.33)$ & $14.63 \pm 6.37^{\mathrm{a}}$ \\
Dead & $8(26.67)$ & $48.49 \pm 12.39^{\mathrm{b}}$ \\
\hline
\end{tabular}

Means bearing different superscripts are significantly different at $\mathrm{P}<0.05, \mathrm{SE}=$ Standard error

The probable reason for failure to detect survivin in normal and tumorous canine cutaneous and subcutaneous tissue by immunohistochemistry could be due to the lack of cross-reactivity of human anti-survivin monoclonal antibody to canine survivin antigen.

The survivin gene expression study indicated that the malignant tumors express a higher level of survivin than benign types and have diagnostic and prognostic importance.

High survivin expression by neoplasms correlates with more aggressive behavior and shortened survival time as compared to cancers that are survivin negative [29]. All eight dogs that died during postsurgical follow-up period revealed overexpression of survivin gene which indicated the association between malignancy and survivin expression and its prognostic significance. Several earlier workers also have indicated the prognostic importance of survivin in various malignant neoplasms of humans and animals [1,32-37]. The results of the study also indicating that there was no difference in the level of expression of survivin between recurrence and alive groups as some of the alive cases also revealed higher surviving expression.

Statistical analysis of Kaplan-Meier survival curves for dogs with under- and over-expression groups in relation to various postsurgical outcomes using median cutoff value of 3.74 was compared with log-rank test. Mean survival time for dogs with survivin expression more than the median value was observed to be shorter, indicating that survivin expression correlates with the postsurgical outcome, and the higher expression above the median value has a poor prognosis.

\section{Conclusion}

It may be concluded that by setting median cutoff value for survivin gene expression (3.74 as in the present 40 cases of cutaneous and subcutaneous tumors), prognosis of tumor patients could be determined with relation to various postsurgical outcome groups. Survivin gene expression value lower than median cutoff value will have a more favorable prognosis and guarded prognosis when the value is higher than the median value.

However, the results from the current study need to be further validated in a large number of cases.

\section{Authors' Contributions}

NK: Carried out the research work. SR and NK: Sample collection, gross, histopathological work, photography, and interpretation of data, collection of scientific literatures, and preparation of first draft of the manuscript were done by these authors. SR, MLS, HDN, and AK: Supervised the work. RL: Contributed in sample collection. NK, SMB, and KMP: Contributed in RT-PCR. TKK: Helped in research work. All authors read and approved the final manuscript.

\section{Acknowledgments}

The authors are thankful to the Head of the Department of Surgery of the College for the permission granted to collect samples and Institute of Animal Health and Veterinary Biologicals (IAH and VB), for providing facilities to carry out RT-PCR work.

\section{Competing Interests}

The authors declare that they have no competing interests.

\section{References}

1. Mobahat, M., Narendran, A. and Riabowol, K. (2014) Survivin as a preferential target for cancer therapy. Int. J. Mol. Sci., 15: 2494-2516.

2. Jemal, A., Seigel, R., Ward, E., Hao, Y., Xu, J., Murray, T. and Thun, M.J. (2008) Cancer statistic. Cancer J. Clin., 58: 71-96.

3. Murphy, S., Sparkes, A.H., Blunden, A.S., Brearley, M.J. and Smith, K.C. (2006) Effects of stage and number of tumours on prognosis of dogs with cutaneous mast cell tumours. Vet. Record, 158(9): 287-291

4. Chikweto, A., Mcneil, P., Bhaiyat, M.I., Stone, D. and Sharma, R.N. (2011) Neoplastic and nonneoplastic cutaneous tumours of dogs in Grenada, West Indies. Int. Sch. Res. Netw., 2011: 6.

5. Dayananda, T.S., Rao, S., Byregowda, S.M., Satyanarayana, M.L., Jayachandra, K.C. and Shilpa, V.T. (2009) Proliferation index in hemangioma and hemangiosarcoma of dogs. Indian Vet. J., 86: 454-456.

6. Jayachandra, K.C., Rao, S., Byregowda, S.M., Satyanarayana, M.L., Dayananda, T.S. and Shilpa, V.T. (2011) Pathology of mammary gland tumours in canines. Indian Vet. J., 88(1): 74-75.

7. Mukaratirwa, S., Chipunza, J. and Chitanga, S. (2005) Canine cutaneous neoplasms: Prevalence and influence of age, sex and site on the presence and potential malignancy of cutaneous neoplasms in dogs from Zimbabwe. J. S. Afr. Vet. Assoc., 76: 59-62.

8. Pawan, K. (2008) Studies on Pathology and Evaluation of Expression of C-erbB2 Inspontaneous Canine Mammary Tumours. M.V.Sc Thesis. Izatnagar: Indian Veterinary Research Institute.

9. Chiti, L. and Amber, E.I. (1992) Incidence of tumours seen at the faculty of veterinary medicine, university of Zambia: A four year retrospective study. Zimbabwe Vet. J., 3: 143-147.

10. Shakir, S.A. and Sundararaj, A. (1994) Skin neoplasms of dogs in madras city. Indian J. Vet. Pathol., 18: 154-158. 
11. Martins, A.M., Elia, T. and Jose, L.G. (2002) Retrospective review and systemic study of mammary tumours in dogs and characteristics of the extracellular matrix. Braz. J. Vet. Res. Anim. Sci., 39(1): 38-42.

12. Sorenmo, K.U., Shofer, F.S. and Goldschmidt, M.H. (2000) Effect of spaying and timing of spaying on survival of dogs with mammary carcinoma. J. Vet. Intern. Med., 14: 266-270.

13. Donnay, I., Rauis, J., Devleeschouwer, N., Wouters, B., Leclerc, G. and Verstegen, J. (1995) Comparison of estrogen and progesterone receptor expression in normal and tumour mammary tissues from dogs. Am. J. Vet. Res., 56(9): 1188-1194.

14. Salvesen, G.S. and Duckett, C.S. (2002) IAP proteins: Blocking the road to death's door. Nat. Rev. Mol. Cell Biol., 3: 401-410.

15. Altieri, D.C. and Marchisio, C. (1999) Survivin apoptosis: An interloper between cell death and cell proliferation in cancer. Lab. Invest., 79(11): 1327-1333.

16. Adida, C., Berrebi, D., Peuchmaur, M., Mugica, R.M. and Altieri, D.C. (1998) Antiapoptosis gene, survivin, and prognosis of neuroblastoma. Lancet, 351: 882-883.

17. Boidot, R., Vegran, F., Jacob, D., Chevrier, S., Gangneux, N., Taboureau, J. and Oudin, C., Rainville, V., Mercier, L., Lizard-Nacol, S. (2008) The expression of BIRC5 is correlated with loss of specific chromosomal regions in breast carcinomas. Genes Chromosomes Cancer, 47: 299-308.

18. Bongiovanni, L., Romanucci, M., Malatesta, D., Andrea, A.D., Ciccarelli, A. and Della Salda, L. (2014) Survivin and related proteins in canine mammary tumours: Immunohistochemical expression. Vet. Pathol., 134: 1-7.

19. Upadhyay, R., Khurana, R., Kumar, S., Ghoshal, U.C. and Mittal, B. (2011) Role of survivin gene promoter polymorphism $(-31 \mathrm{G}>\mathrm{C})$ in susceptibility and survival of esophageal cancer in northern India. Ann. Surg. Oncol., 18: 880-887.

20. Yang, L., Zhu, H., Zhou, B., Gu, H., Yan, H., Tang, N., Dong, H., Sun, Q., Cong, R., Chen, G. and Wang, B. (2009) The association between the survivin $C-31 G$ polymorphism and gastric cancer risk in a Chinese population. Dig. Dis. Sci., 54: 1021-1028.

21. Borges, B.N., Burbano, R.R. and Harada, M.L. (2011) Survivin-66 31C/G polymorphism and gastric cancer risk in a Brazilian population. Clin. Exp. Med., 11: 189-193.

22. Dimitrakopoulos, F.I., Marousi, S., Antonacopoulou, A.G., Floratou, K., Bravou, V., Kottorou, A., Stavropoulos, M., Koutras, A.K., Scopa, C.D. and Kalofonos, H.P. (2011) The survivin-31 snp in human colorectal cancer correlates with survivin splice variant expression and improved overall survival. Cell Oncol., 34: 381-391.

23. Theodoropoulos, G.E., Michalopoulos, N.V., Panoussopoulos, S.G., Taka, S. and Gazouli, M. (2010) Effects of caspase-9 and survivin gene polymorphisms in pancreatic cancer risk and tumour characteristics. Pancreas, 39: 976-980.

24. Kawata, N., Tsuchiya, N., Horikawa, Y., Inoue, T.,
Tsuruta, H., Maita, S., Satoh, S., Mitobe, Y., Narita, S. and Habuchi, T. (2011) Two survivin polymorphisms are cooperatively associated with bladder cancer susceptibility. Int. J. Cancer, 129: 1872-1880

25. Qin, C., Cao, Q., Li, P., Ju, X., Wang, M., Chen, J., Liu, N., Yin, Y. and You, Y. (2012) Functional promoter-31G $>$ C variant in survivin gene is associated with risk and progression of renal cell cancer in a Chinese population. PLoS One, 7: 288-289.

26. Kostić, M., Nikolić, N., Ilić, B., Carkić, J., Milenković, S. and Vukadinović, M. (2013) Analysis of polymorphism in the survivin gene promoter as a potential risk factor for head and neck cancers development. Srp. Arh. Celok. Lek., 141: 304-307.

27. Lauxen, I., Oliveira, M.G., Rados, P.V., Lingen, M.W., Nor, J.F. and Sant'anaFilho, M. (2014) Immunoprofiling of oral squamous cell carcinomas reveals high p63 and survivin expression. Oral Dis., 20: 76-80.

28. Brundage, M.D., Davies, D. and Mackillop, W.J. (2002) Prognostic factors in non-small cell lung cancer; A decade of progress. Chest, 122: 1037-1057.

29. Li, J., Zhang, Z., Dai, Z., Anthony, P.P., Christoph, P., Carl, M., Yian, W. and Ming, Y. (2003) RASSF1 a promoter methylation and kras2 mutations in non-small cell lung cancer. Neoplasia., 5: 362-366.

30. Uchide, T., Takatsu, N., Fujimori, Y., Fukushima, U. and Itoh, H. (2005) Expression of survivin mRNA in dog tumours. DNA Sequence, 16: 329-334.

31. Altieri, D.C. (2008) Survivin, cancer networks and pathway-directed drug discovery. Nat. Rev. Cancer, 8: 61-70.

32. Jaiswal, P.K., Goel, A. and Mittal, R.D. (2015) Survivin: A molecular biomarker in cancer. Indian J. Med. Res., 141: 389-397.

33. Renn, D.F.U., Daiki, K., Watabe, A.I., Yoshifumi, E. and Tsuyoshi, K. (2014) Prognostic utility of apoptosis index, $\mathrm{Ki}-67$ and survivin expression in dogs with nasal carcinoma treated with orthovoltage radiation therapy. J. Vet. Med. Sci., 76(11): 1505-1512.

34. Elsheikh, S.M., Omar, T.A., Abdel, H.H.S. and Abdelsattar, M.F. (2014) Expression of the antiapoptotic survivin in the adenomatoid odontogenic tumours. Tanta Dent. J., 11: 174-179.

35. Shoeneman, J.K., Ehrhart, E.J., Eickhoff, J.C., Charles, J.B., Powers, B.E. and Thamm, D.H. (2011) Expression and function of survivin in canine osteosarcoma. Cancer Res., 72: 249-259.

36. Wimmershoff, J., Polkinghorne, A., Grest, P., Schade, B., Marchal, T., Keller, S.M. and Guscetti F. (2010) Immunohistochemical Detection of survivin in canine lymphoma. J. Comp. Pathol., 142: 311-322.

37. Lechler, P., Renkawitz, T., Campean, V., Balakrishnan, S., Tingart, M., Grifka J. and Schaumburger J. (2011) The antiapoptotic gene survivin is highly expressed in human chondrosarcoma and promotes drug resistance in chondrosarcoma cells in vitro. BMC Cancer, 11: 120. 